\title{
Effect of Musical Therapy Langgam Jawa on Pre-chemotherapy Anxiety of Cancer Patients
}

Febriana Sartika Sari ${ }^{1 *}$, Winda Fitriani ${ }^{2}$, Innez Karunia Mustikasari ${ }^{1}$, Imam Rosyada ${ }^{3}$, Heni Nur Kusumawati ${ }^{4}$, S. Dwi Sulisetyawati ${ }^{1}$, Ika Subekti Wulandari ${ }^{1}$, Rufaida Nur Fitriana ${ }^{1}$, Mellia Silvy Irdianty ${ }^{1}$

${ }^{1}$ Department of Nursing, Faculty of Health and Sciences, Universitas Kusuma Husada Surakarta, Surakarta, Indonesia; ${ }^{2}$ Department of Oncology, Oncology Hospital Surakarta, Surakarta, Indonesia; ${ }^{3}$ Oncology Installation, Dr. Kariadi General Hospital Medical Center, Semarang, Indonesia; ${ }^{4}$ Poltekkes Kemenkes Surakarta, Surakarta, Indonesia

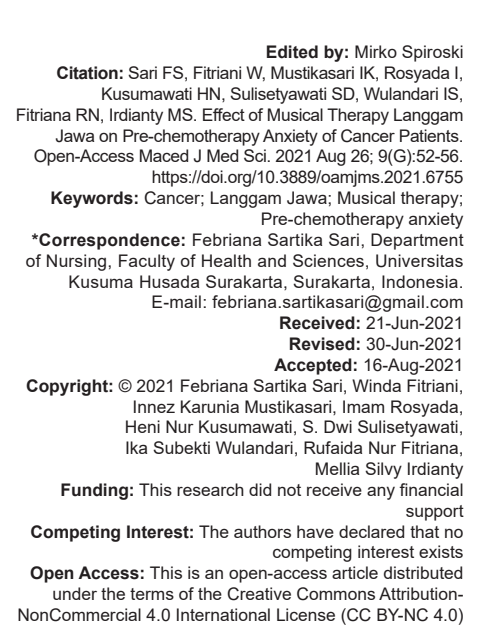

\section{Abstract}

BACKGROUND: Anxiety occurs in cancer patients who are undergoing chemotherapy for the $1^{\text {st }}$ time. Excessive anxiety which occurred in the pre-chemotherapy phase can contribute to the failure of chemotherapy programs. One of attempts to reduce anxiety is providing musical therapy Langgam Jawa.

AIM: The purpose of the research is to identify the effect of musical therapy Langgam Jawa to pre-chemotherapy anxiety score.

METHODS: The research used quasi-experimental design which involved pre-posttest with control group. The research was conducted at a hospital in Central Java. The population was cancer patients who undergoing chemotherapy for the $1^{\text {st }}$ time and experienced pre-chemotherapy anxiety. Samples were selected with purposive sampling technique that met inclusion criteria. Subjects were 42 respondents consisting of 21 in each group obtained by simple random sampling technique. Health education and deep breathing exercise were provided to the contro group, while the treatment group obtained health education, deep breathing exercise, and musical therapy Langgam Jawa. The measurement of pre-chemotherapy anxiety in the cancer patients was using State-Trait Anxiety Inventory. An independent t-test performed the analysis.

RESULTS: The results showed that pre-chemotherapy anxiety score decreases significantly in those two groups ( $p$-value: $0.001 ; \alpha: 0.05$ ). The treatment group showed a higher decrease of pre-chemotherapy anxiety than the control group.

CONCLUSION: The finding highlights musical therapy Langgam Jawa is effective to reduce pre-chemotherapy anxiety of cancer patients. It is recommended to apply musical therapy Langgam Jawa for cancer patients who're undergoing chemotherapy.

\section{Introduction}

Cancer disease is a major public health problem worldwide and the second leading cause of death globally, and is responsible for about 10 million deaths per year. Globally, about one in six deaths is due to cancer. Approximately $70 \%$ of deaths from cancer occur in low- and middle-income countries such as Indonesia (Cancer and Organization, 2020; Ferlay, 2020). Cancer is a group of disease characterized by the uncontrolled cell proliferation [1], [2], [3]. Cancer is one of the chronic diseases that receive primarily focused from the country besides four other chronic diseases such as stroke, diabetes mellitus, and chronic obstructive pulmonary disease. In Indonesia, the prevalence of cancer in 2018 reached 1.79 in 1000 population, an increase from 2013 which was 1.4 in 1000 population. In indonesia as much as 136.2 in 100,000 population [1]. Indonesia is the $8^{\text {th }}$ country with the most cases in Southeast Asia and $23^{\text {rd }}$ in Asia [4], [5].
One of the cancer treatments is chemotherapy. Chemotherapy treatments are used to inhibit vigorously growing malignant cells with anticancer agents [6]. Chemotherapy has physical and psychological side effects in cancer patients. The common physical side effects observed during the period of chemotherapy treatment are nausea, vomiting, hair loss (alopecia), mucositis (inflammation of the lining of the digestive tract), dermatitis, fatigue, dry skin, the skin can turn black, no appetite, and sore bones, and myelosuppression (decreased production of blood cells, hence also immunosuppression) [6], [7]. Patients will experience fear or anxiety about the actions and side effects of the chemotherapy [8].

Cancer patients who are undergoing chemotherapy for the $1^{\text {st }}$ time often overestimate the danger and underestimate their ability so that they experience pre-chemotherapy anxiety. Anxiety that occurs continuously and is not resolved immediately can lead to panic attacks. A panic attack is a rapid, intense, and escalating episode of anxiety lasting 
15-30 min. The individual experiences great emotional fear and physiological discomfort [9]. Anxiety can cause stimulation of the cerebral cortex which, in turn, can stimulate the vomiting center, allowing for an increase in complaints of nausea and vomiting due to chemotherapy. Treatment to prevent and handle anxiety in pre-chemotherapy period is very important to make the patient feel comfort and ready for the chemotherapy [10].

One of the therapies to reduce prechemotherapy anxiety is musical therapy. Musical therapy has been used in nursing environments as a strategy to reduce anxiety, increasing rest, and sleep in patients [11], [12]. The previous study showed that musical therapy Langgam Jawa reduces anxiety in patients pre-operative [13]. Traditional music is one of the relaxation music because it can improve physical and physiological functions [14]. The other research on traditional music showed that Turkish music was effective in reducing diastolic blood pressure and increases comfort of patients [15].

A preliminary study conducted at a Hospital in Central Java, through survey on five prechemotherapy patients by giving the State-Trait Anxiety Inventory (STAI) questionnaire. It was found that all patients had anxiety. Three patients said that they are worried about the chemotherapy process for the $1^{\text {st }}$ time and the side effects. An interview was conducted with the nurse. The nurse stated that they provide health education regarding chemotherapy and giving deep breathing exercise to patients before receiving first chemotherapy based on the standard operational procedure in the hospital. However, some of the patients still have anxiety although already receive health education and deep breathing exercises.

The purpose of this study was to determine the effect of musical therapy Langgam Jawa on prechemotherapy anxiety of cancer patients.

\section{Ethics approval}

This research has ethical clearance by the Committee of Ethics of Moewardi Hospital Surakarta with ID number 832/VII/HERC/2020. Respondents were voluntary, and the respondents had the right to withdraw at any time without further explanation. Data were stored securely and anonymously in compliance with the data protection act.

\section{Materials and Methods}

The study applied a quasi-experimental design which involved pre-posttest with a control group. The study was conducted at a Hospital in Central Java. The health education regarding chemotherapy and deep breathing exercise was applied to control group, while the treatment group obtained health education about chemotherapy, deep breathing exercise, and musical therapy Langgam Jawa.

The population was cancer patients who undergoing chemotherapy for the $1^{\text {st }}$ time and experienced pre-chemotherapy anxiety at a Hospital in Central Java. The samples were 42 respondents (the cancer patients) who were willing to participate and had pre-chemotherapy anxiety (screening score of anxiety with STAI). Samples were selected with purposive sampling technique that met inclusion criteria. The inclusion criteria were cancer patients who're undergoing chemotherapy for the $1^{\text {st }}$ time and experienced pre-chemotherapy anxiety; patients who understand Javanese language and have preferences in music Langgam Jawa; and patients who were voluntary become research respondents. Respondents who had consuming anxiety drugs, experienced hearing loss, and experienced loss of consciousness were excluded from the study. Samples were 42 respondents consisting of 21 in each group obtained by simple random sampling technique. The research variable was musical therapy Langgam Jawa as independent variables and pre-chemotherapy anxiety as dependent variable.

The measurement of pre-chemotherapy anxiety of the cancer patients was using STAI. STAI was created by Spielberger in 1980 and translated by the researchers. STAI questionnaire consists of 20 items with response options based on a selfreported Likert scale where each item is given a score of 1-4. On the A-State indicator (anxious state) with a positive statement, it is stated with a score of $1=$ not at all, 2 = somewhat, $3=$ moderately so, and $4=$ very much so. The state anxiety score ranges from a minimum of 20 to a maximum of 80 . A low score indicates no or little anxiety while a higher score indicates a higher level of anxiety. STAI questionnaire grid is A-State: Favorable $(1,2,5,8$, $10,11,15,16,19$, and 20$)$ while unfavorable $(3,4,6$, $7,9,12,13,14,17$, and 18) [16]. STAI has a validity test result value of $0.390-0.736$ which means it is valid and a Cronbach's alpha value of 0.960 which means it is reliable [17].

The respondents in the intervention and control groups completed STAI questioner before both groups were given treatment. The treatment group received health education, deep breathing exercise, and musical therapy Langgam Jawa. In contrast, the control group received health education and deep breathing exercise only. The treatment group received a 15 min musical therapy Langgam Jawa. A 15 min after a complete musical therapy session, the nurse reassessed pre-chemotherapy anxiety scores in both the control and intervention groups. 
The tittle of Langgam Jawa music in the research is Luntur-Langgam Jawa by Gesang. The duration of the song is about $4: 51 \mathrm{~s}$. The song was played repeatedly in duration $15 \mathrm{~min}$. The pre-posttest of prechemotherapy anxiety using STAI was performed to the respondents.

The analysis used univariate and bivariate analysis with a statistic test of a paired t-test and independent t-test. The researcher performed the statistical data analysis with SPSS.

\section{Results}

The study showed that the majority of the respondents in both the treatment and control groups were women $(61.9 \%$ in the treatment group and $52.4 \%$ in the control group) (Table 1).

Table 1: Characteristics of cancer patients undergoing chemotherapy, August 2020 ( $n=42)$

\begin{tabular}{llllll}
\hline Characteristics & \multicolumn{2}{l}{ Treatment group } & & & Control group \\
\cline { 2 - 3 } & $\mathrm{n}$ & & & $\mathrm{n}$ & $\%$ \\
\hline Gender & 8 & 38.1 & & 10 & 47.6 \\
Men & 13 & 61.9 & & 11 & 52.4 \\
Women & & &
\end{tabular}

The study found that cancer patients in the treatment group who received musical therapy Langgam Jawa had a mean score of prechemotherapy decrease from 60.1 to 35.52, while in the control group who received health education and deep breathing exercise also showed a decrease from 60.5 to 51.81. The dependent t-test shows a $p=0.001(p<0.05)$ which means that there is significant difference between pre-chemotherapy anxiety of cancer patients before and after receiving interventions both in the treatment and control groups (Table 2).

Table 2: Pre-chemotherapy anxiety of cancer patients in the treatment group and control group, August $2020(n=42)$

\begin{tabular}{llllllll}
\hline Variable & Group & $\mathrm{n}$ & $\begin{array}{l}\text { Mean } \\
\text { pre-test }\end{array}$ & $\begin{array}{l}\text { Mean } \\
\text { post-test }\end{array}$ & $\begin{array}{l}\text { Mean } \\
\text { diff. }\end{array}$ & SD & p-value \\
\hline $\begin{array}{l}\text { Pre-chemotherapy } \\
\text { anxiety }\end{array}$ & $\begin{array}{l}\text { Treatment } \\
\text { group }\end{array}$ & 21 & 60.1 & 35.52 & 24.58 & $6.97-7.64$ & 0.001 \\
& $\begin{array}{l}\text { Control } \\
\text { group }\end{array}$ & 21 & 60.5 & 51.81 & 8.69 & $6.71-6.96$ & 0.001 \\
& & & & & & & \\
\hline
\end{tabular}

The study identified that mean score of prechemotherapy anxiety of cancer patients in the treatment group had greater decrease than the control group. The independent t-test shows $p=0.001$ ( $p<0.05)$ which means that there is a significant difference between pre-chemotherapy anxiety of cancer patients in the treatment and control groups (Table 3).

Table 3: Pre-chemotherapy anxiety of cancer patients post-test in the treatment group and control group, August $2020(n=42)$

\begin{tabular}{lllllll}
\hline Variable & Group & $\mathrm{n}$ & Mean & SD & Mean diff. & p-value \\
\hline Pre-chemotherapy anxiety & Treatment group & 21 & 35.52 & 7.64 & 16.29 & 0.001 \\
& Control group & 21 & 51.81 & 6.96 & & \\
\hline
\end{tabular}

\section{Discussion}

The majority of the respondents were women both in the control and treatment groups. The greater incidence of anxiety in women is not exclusive of oncology. These findings coincide with other study which identified greater pre-chemotherapy anxiety in women compared to men [18]. Women have $60 \%$ more probabilities of developing an anxiety throughout their life [19]. Women show more biological anxiety and stress reactivity than men. Anxiety in men is more likely to have a lower risk of experiencing anxiety because men are more active and explorative than women [18], [20].

Anxiety is one of the most common problems experienced by patients receiving their first chemotherapy treatment [21]. Anxiety is caused by fear of treatment that has never been obtained so that it puts forward fear and anxiety about the effects of changes that occur on them. This is in line with the theory that in patients who are undergoing chemotherapy for the $1^{\text {st }}$ time, patients often overestimate the danger and underestimate their ability. Patients will experience fear or anxiety about the actions and side effects of the chemotherapy [8].

Pre-chemotherapy anxiety in cancer patients decreased significantly both in the control and treatment groups $(p<0.05)$. In the control group, the health education regarding the chemotherapy and deep breathing exercise was applied as basic intervention. The health education and deep breathing exercise can reduce pre-chemotherapy anxiety in the control group with mean score decreased from 60.5 to 51.81 . This finding is consistent with the previous study. Information regarding side effects of treatment, side effect management strategies, and orientation to the infusion center are the most important topics of education that reduce anxiety. In addition, education performed by nurses before the first chemotherapy infusion in a quiet environment is most effective [21]. Another study explained that health education using brochure media is an effective strategy to increase knowledge [22]. The level of knowledge is associated with the psychological problems such as anxiety [10].

Besides that, the patient in the control group not only received health education but also deep breathing exercise. National Safety Council explains that relaxation techniques are effective treatment for managing anxiety [12]. Deep breathing exercise is proven to decrease anxiety [23]. The other study explains that deep breathing exercise is the effective treatment for individuals who experience anxiety (Harris, 2020) [24]. Deep breathing can physiologically cause relaxing effects involving the parasympathetic nerves in the central nervous system. The function of one of the parasympathetic nerves is to reduce the production of adrenal hormone or epinephrine (stress 
hormone) and increase the secretion of non-adrenaline or non-epinephrine hormones (relax hormone) so that anxiety and tension decrease so that they become more relaxed [25].

The research shows that in the treatment group, decrease in pre-chemotherapy anxiety indicates greater decrease than the control group after the intervention is applied. The health education, deep breathing exercise, and musical therapy Langgam Jawa are applied in the treatment group. The interventions reduce pre-chemotherapy anxiety with mean score decrease from 60.1 to 35.52. The additional intervention that is musical therapy Langgam Jawa performed great effect in reducing anxiety. Music listening had a consistently positive and statistically significant effect on reducing psychological parameters of pre-procedural state anxiety [26]. Listening to music reduces anxiety in patients undergoing the medical procedure, provided that the music complies with the patient's preferences [27]. In this study, one of the inclusion criteria is understanding Javanese language and has preferences in music Langgam Jawa. These criteria represent the respondents' musical preferences that support in reducing pre-chemotherapy anxiety.

The music Langgam Jawa has been influenced by that local music or local ethnic, both from its interpretation and of its instrument playing, and therefore resulted the style of new Keroncong music (Siswanto et al., 2004; Larasati, 2014). The previous study showed that musical therapy Langgam Jawa reduces anxiety in patients pre-operative [13]. The characteristic of Langgam Jawa used in the study was Keroncong with Gesang as the singer. Music Langgam Jawa is familiar and increasingly preferred in the elderly in Central Java. Javanese traditional music can reduce anxiety of the elderly [24]. Traditional music is one of the relaxation music coincide in a research conducted by Shimizu et al. (2013) showing that traditional Japanese music improves physical and physiological functions [14]. The other research on traditional music showed that Turkish music was effective in reducing diastolic blood pressure [15].

Musical therapy Langgam Jawa can synchronize the body's rhythm by means of vibration and stimulate a person to feel calm, suppress the release of cortisol or stress hormones so that gradually the formation of immunity is not disturbed by increasing endogenous opiates (endorphins and encephalins) and reducing catecholamines so that body resistance sufferer increases. Patients can feel comfortable when hearing soft music. Soft music can slow down the heart rate, expand the work of breathing, and finally soothe the soul. The melody and genre of the music stimulate the body to produce serotonin and endorphin and giving relaxation effect to the body. Music elicits responses promoting positive emotions, alleviation of stress, and immune function [28], [29], [30].

\section{Conclusion}

The research concludes that health education, deep breathing exercise, and musical therapy Langgam Jawa lead to a significantly decrease in the pre-chemotherapy anxiety of cancer patients. The research has identified that musical therapy Langgam Jawa leads to greater decrease of pre-chemotherapy anxiety than given health education and deep breathing exercise only. The research recommends that musical therapy Langgam Jawa is an alternative intervention at a hospital that reduces pre-chemotherapy anxiety. Future research should use a larger sample and compare the musical therapy Langgam Jawa with the other genre of music.

\section{Acknowledgments}

The researcher is grateful to the Universitas Kusuma Husada Surakarta, which has supported the publication funding of this article and all subjects participating in this study.

\section{References}

1. World Health Organization. Globocan 2020. Vol. 419. Geneva World Health Organization; 2020. p. 1-2.

2. American Cancer Society. Cancer Facts and Figures. American Cancer Society. American Cancer Society" 2020. p. 1-52. Available from: http://www.cancer.org/acs/groups/content/@ nho/documents/document/caff2007pwsecuredpdf.pdf. [Last accessed on 2021 Feb 01]. https://doi.org/10.1080/15398285. 2012.701177

3. Siegel RL, Miller KD, Jemal A. Cancer statistics, 2020. CA Cancer J Clin. 2020;70(1):7-30.

PMid:31912902

4. Kemetrian Kesehat RI. State of Health Inequality. Indonesia: Kemetrian Kesehat RI; 2017.

5. Pangribowo S. Beban Kanker di Indonesia. Indonesia: Kemetrian Kesehat RI; 2019. p. 8-9.

6. Alam A. Chemotherapy treatment and strategy schemes: A review. Open Access J Toxicol. 2018;2(5):555600.

7. Nurgali K, Jagoe RT, Abalo R. Adverse effects of cancer chemotherapy: Anything new to improve tolerance and reduce sequelae? Front Pharmacol. 2018;9:245. https://doi. org/10.3389/978-2-88945-482-2 PMid:29623040

8. Lebel S, Beattie S, Arès I, Bielajew C. Young and worried: Age and fear of recurrence in breast cancer survivors. Health Psychol. 2013;32(6):695-705. https://doi.org/10.1037/a0030186 PMid:23088176

9. Hapter C, Rch JO, Raske MI, Arch J, Craske, MJ. Panic disorder: In: Craighead WE, Miklowitz DJ, Craighead LW, editors. Psychopathology: History, Diagnosis, and Empirical 
Foundations. Ch. 4. New York: Wiley; 2008. p. 1-64.

10. Tian J, Jia LN, Cheng ZC. Relationships between patient knowledge and the severity of side effects, daily nutrient intake, psychological status, and performance status in lung cancer patients. Curr Oncol. 2015;22(4):e254-8. https://doi. org/10.3747/co.22.2366

PMid:26300675

11. Jasemi M, Aazami S, Zabihi RE. The effects of music therapy on anxiety and depression of cancer patients. Indian J Palliat Care. 2016;22(4):455-8. https://doi. org/10.4103/0973-1075.191823 PMid:27803568

12. Noor Z, Junaidi J. Reducing anxiety levels in the elderly through Javanese style music therapy. J Keperawatan Indonesia. 2010;13(3):195-201. https://doi.org/10.7454/jki.v13i3.252

13. Triatna A, Sucipto A, Wiyani C. Javanese music to reduce anxiety in preoperative patients. J Kesehatan. 2018;9(2):170. https://doi.org/10.26630/jk.v9i2.680

14. Shimizu N, Umemura T, Hirai T, Tamura T, Sato K, Kusaka $Y$. Effects of movement music therapy with the Naruko clapper on psychological, physical and physiological indices among elderly females: A randomized controlled trial. Gerontology. 2013;59(4):355-67. https://doi.org/10.1159/000346763 PMid:23615154

15. Bekiroğlu T, Ovayolu N, Ergün Y, Ekerbiçer HC. Effect of Turkish classical music on blood pressure: A randomized controlled trial in hypertensive elderly patients. Complement Ther Med. 2013;21(3):147-54. https://doi.org/10.1016/j. ctim.2013.03.005

PMid:23642944

16. Spielberger $C D$. State-trait anxiety inventory for adults: Selfevaluation questionnaire. Anxiety. 2012;91(5):75.

17. Gustafson LW, Gabel P, Hammer A, Lauridsen HH, Petersen LK, Andersen B, et al. Validity and reliability of State-Trait Anxiety Inventory in Danish women aged 45 years and older with abnormal cervical screening results. BMC Med Res Methodol. 2020;20(1):89. https://doi.org/10.1186/s12874-020-00982-4 PMid:32326886

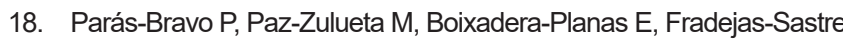
V, Palacios-Ceña D, Fernández-de-Las-Peñas $C$, et al. Cancer patients and anxiety: A gender perspective. Int J Environ Res Public Health. 2020;17(4):1302. https://doi.org/10.3390/ijerph17041302 PMid:32085538
19. Donner NC, Lowry CA. Sex differences in anxiety and emotional behavior. Pflugers Arch Eur J Physiol. 2013;465(5):601-26. https://doi.org/10.1007/s00424-013-1271-7 PMid:23588380

20. Hosseini L, Khazali H. Comparing the Level of Anxiety in Male and Female School Students. Proc Soc Behav Sci. 2013;84:41-6.

21. Garcia $S$. The effects of education on anxiety levels in patients receiving chemotherapy for the first time: An integrative review. Clin J Oncol Nurs. 2014;18:A1-6.

22. Prawesti I, Haryanti F, Lusmilasari L. Effect of health education using video and brochure on maternal health literacy. Belitung Nurs J. 2018;4(6):612-8. https://doi.org/10.33546/bnj.176

23. Hargiana G, Keliat BA, Mustikasari M. The effects of cognitive behavioral therapy on smoking behavior and anxiety in heads of family who smoke. J Keperawatan Indones. 2018;21(2):117-26. https://doi.org/10.7454/jki.v21i2.770

24. Harris SJ. The Time to Relax is when you don't have Time for it; 2012.

25. Sellakumar GK. Effect of slow-deep breathing exercise to reduce anxiety among adolescent school students in a selected higher secondary school in Coimbatore, India. J Psychol Educ Res. 2015;23(1):54-72.

26. Gillen E, Biley F, Allen D. Effects of music listening on adult patients' pre-procedural state anxiety in hospital. Int J Evid Based Healthc. 2008;6(1):24-49. https://doi. org/10.1111/j.1744-1609.2007.00097.x

PMid:21631813

27. Jeppesen E, Pedersen CM, Larsen KR, Walsted ES, Rehl A, Ehrenreich $\mathrm{J}$, et al. Listening to music prior to bronchoscopy reduces anxiety-a randomised controlled trial. Eur Clin Respir J. 2019;6(1):1583517. https://doi.org/10.1080/20018525.2019.1583517 PMid:30915199

28. Larasati S. Gaya Vokal Waldjinah pada Langgam Keroncong Universitas Pendidikan Indonesia; 2014. p. 2010-1.

29. Yusli UD, Rachma N. The effect of giving Javanese gamelan music on the level of anxiety of the elderly in the social service home for the elderly in Semarang. J Perawat Indonesia. 2018;3(1):72-78. https://doi.org/10.32584/jpi.v3i1.290

30. Gangrade A. The effect of music on the production of neurotransmitters, hormones, cytokines, and peptides: A review. Music Med. 2012;4(1):40-3. https://doi. org/10.1177/1943862111415117 